\title{
H2AC14 Gene
}

National Cancer Institute

\section{Source}

National Cancer Institute. H2AC14 Gene. NCI Thesaurus. Code C162913.

This gene plays a role in histone-mediated nucleosome formation. 